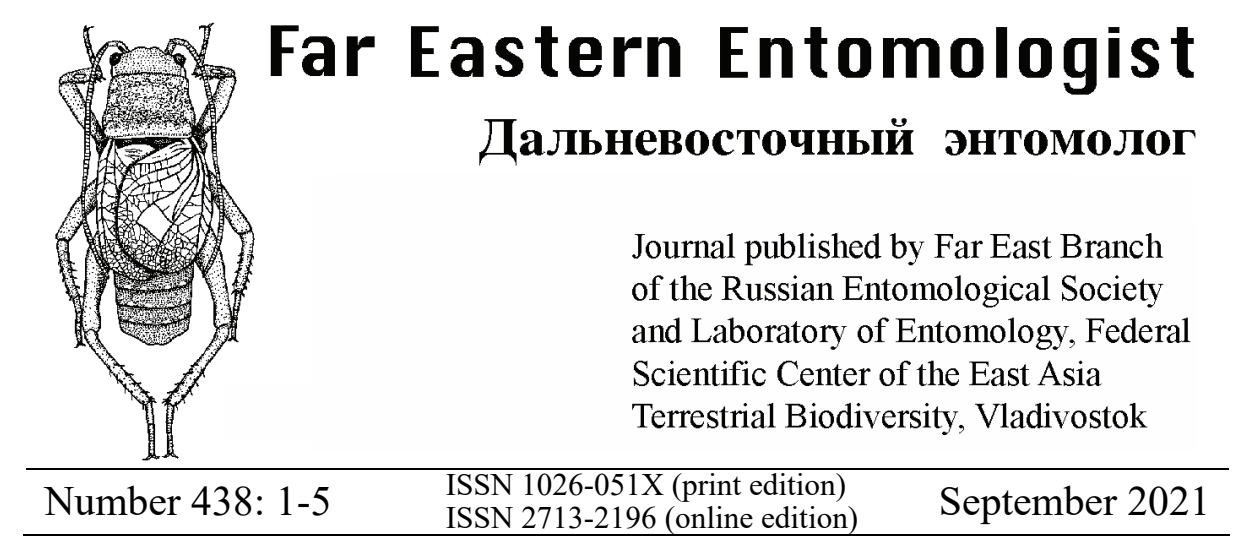

https://doi.org/10.25221/fee.438.1

http://zoobank.org/References/07647FE3-8BC5-440C-B1B4-0DF797507AF8

\title{
A NEW SPECIES OF THE GENUS EXRHYNCHITES VOSS, 1930 (COLEOPTERA: RHYNCHITIDAE) FROM VIETNAM
}

$$
\text { A. A. Legalov }{ }^{1,2,3)}
$$

1) Institute of Systematic and Ecology of Animals, Siberian Branch, Russian Academy of Sciences, Frunze street-11, Novosibirsk, 630091, Russia. E-mail: fossilweevils@gmail.com

2) Altai State University, Lenina-61, Barnaul, 656049, Russia.

3) Tomsk State University, Lenina Prospekt 36, Tomsk, 634050 Russia.

Summary. Exrhynchites storozhenkoi sp. n. is described and illustrated from North Vietnam. The new species differs from other congeners in the body without metallic blue luster, cowered with dense yellow-brown hairs, and sclerotized armament of the endophallus.

Key words: beetles, Curculionoidea, Rhynchitinae, Deporaini, taxonomy, new species, Oriental Region.

А. А. Легалов. Новый вид рода Exrhynchites Voss, 1930 (Coleoptera: Rhynchitidae) из Вьетнама // Дальневосточный энтомолог. 2021. N 438. C. 1-5.

Резюме. Из Северного Вьетнама описан Exrhynchites storozhenkoi sp. n., который отличается от остальных видов рода покрытым густыми желтокоричневыми волосками телом без металлически-синего блеска и склеротизованным вооружением эндофаллуса.

\section{INTRODUCTION}

The tribe Deporaini is a specialized group of the subfamily Rhynchitinae, which is characterized by the gastral spicula directed to left - forward, exposed a part of the 
propygidium and pygidium, and one- or two-segmented labial palpi (Sawada, 1993; Legalov, 2007). The species of this tribe either develop in sprouts or buds, mining a leaf, or roll leaves in tubes for the larvas (Legalov, 2004). This tribe is distributed mainly in the Oriental region, but several species are recorded in the Holarctic (Legalov, 2007). The genus Exrhynchites Voss, 1930 includes rather large species, which is characterized by the long rostrum, with dense setae at the base of the females, and striae 9 merge with striae 10 near the middle of the elytra. Eighth species of this genus, E. fausti Legalov, 2007, E. himachalensis Legalov, 2007, E. major (Voss, 1932), E. mechtensis Legalov, 2007, E. minor (Voss, 1937), E. puberulus (Faust, 1894), E. subclathratus (Voss, 1938) and E. subplanus (Voss, 1920), were known from North India, Nepal, Myanmar, Thailand, Vietnam, and China. In this paper, a new species from North Vietnam is described. This is the third Vietnamese species of Exrhynchites.

\section{MATERIAL AND METHODS}

Type specimens are kept in ISEA - the Institute of Systematic and Ecology of Animals (Novosibirsk, Russia). Descriptions, body measuring, and photographs were performed using the Zeiss Stemi 2000-C dissecting stereomicroscope. The terminology of weevil body follows those of Legalov (2007) and Lawrence et al. (2010).

\section{TAXONOMY}

\section{Genus Exrhynchites Voss, 1930}

Exrhynchites storozhenkoi Legalov, sp. n.

http://zoobank.org/NomenclaturalActs/9359385E-8043-41B8-90E1-32C0A6B172CC

Figs 1-8

TYPE MATERIAL. Holotype - đ̂, Vietnam: Lai Châu Province, near Lai Châu, VI 2020, local collector (ISEA).

DESCRIPTION. MALE. Body length (without rostrum) $9.0 \mathrm{~mm}$. Rostrum length $3.9 \mathrm{~mm}$. Body black, without metallic blue luster, cowered with dense yellow-brown hairs. Antennal club and tarsi with black hairs. Head subconical behind eye. Mandibles large, externally edentate. Rostrum long, weakly curved, 1.4 times as long as pronotum, 6.2 times as long as wide at apex, 7.3 times as long as wide in middle, 5.7 times as long as wide at base, sparsely punctate, with median carina from base to antennal insertion, glabrous from apex to antennal insertion. Antennal scrobes weak, directed to eye. Eyes large, convex and rounded. Forehead weakly convex, punctate, 1.1 times as wide as rostrum base width. Temples as long as eye. Antennae long, inserted behind middle of rostrum, almost reaching middle of pronotum. Antennomeres 1 and 2 oval. Antennomere 11.6 times as long as wide. Antennomere 2 1.6 times as long as wide, 0.9 times as long as and 0.9 times as narrow as antennomere 1. Antennomeres 3-4 long-conical. Antennomere 33.1 times as long as wide, 1.7 times as long as and 0.9 times as narrow as antennomere 2. Antennomere 42.4 

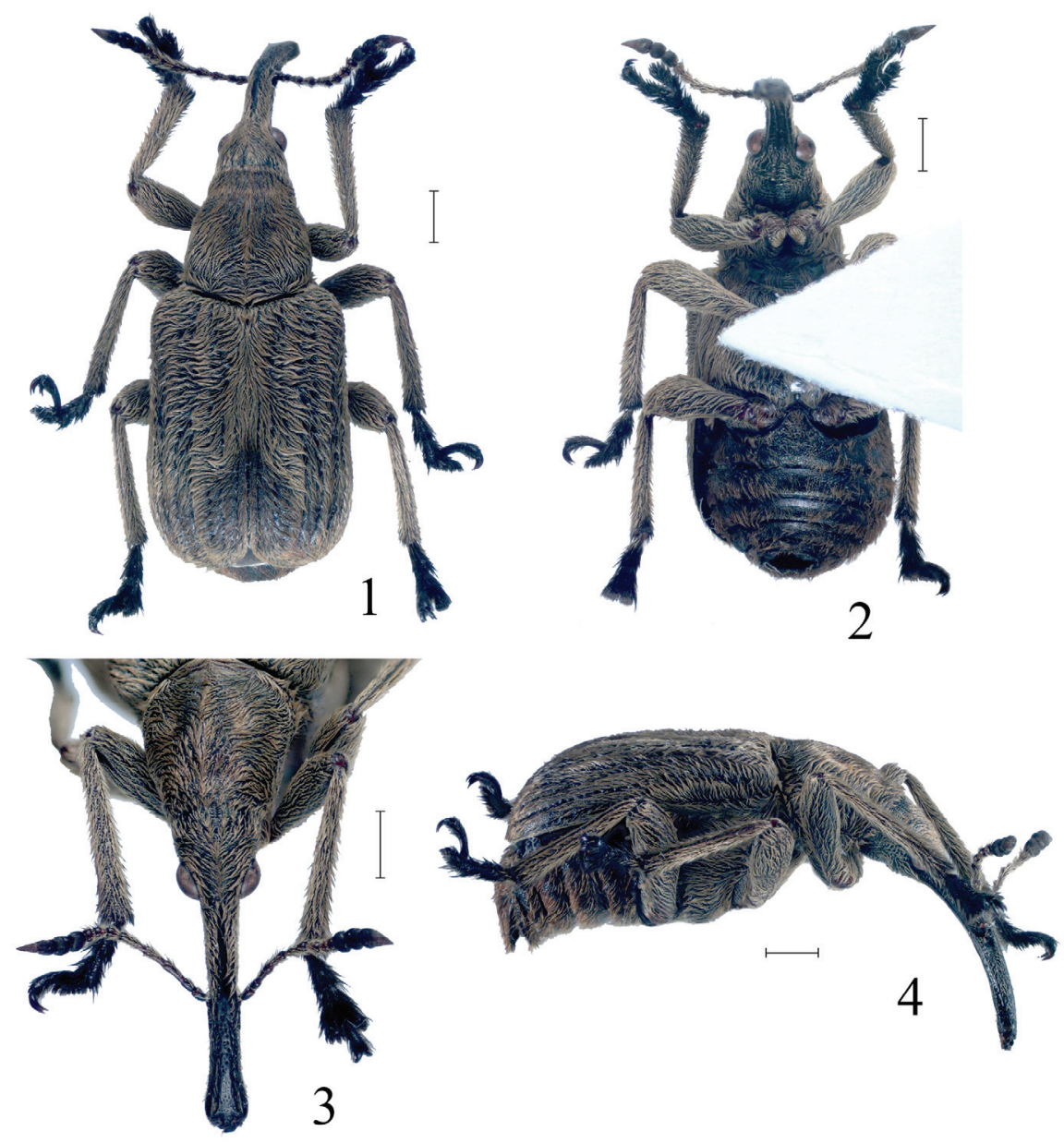

Figs 1-4. Exrhynchites storozhenkoi sp. n., holotype, habitus: 1 - dorsal view; 2 - ventral view; 3 - frontal view; 4 - lateral view. Scale bar $1.0 \mathrm{~mm}$.

times as long as wide, 0.8 times as long as and equal in width to antennomere 3 . Antennomeres 5-8 subconical. Antennomere 50.9 times as long as wide, 0.4 times as long as and 1.19 times as wide as antennomere 4 . Antennomere 61.3 times as long as wide, 1.9 times as long as and 1.3 times as wide as antennomere 5 . Antennomere 7 equal in length and width, 0.8 times as long as and 1.1 times as wide as antennomere 6. Antennomere 80.9 times as long as wide, 0.9 times as long as and equal in width to antennomere 7. Antennal club loose and wide, weakly fattened. Antennomere 9 0.9 times as long as wide, 1.6 times as long as and 1.6 times as wide as antennomere 8. Antennomere 10 subequal to antennomere 9. Antennomere 112.3 times as long as wide, 2.3 times as long as and 0.9 times as narrow as antennomere 10. Pronotum 

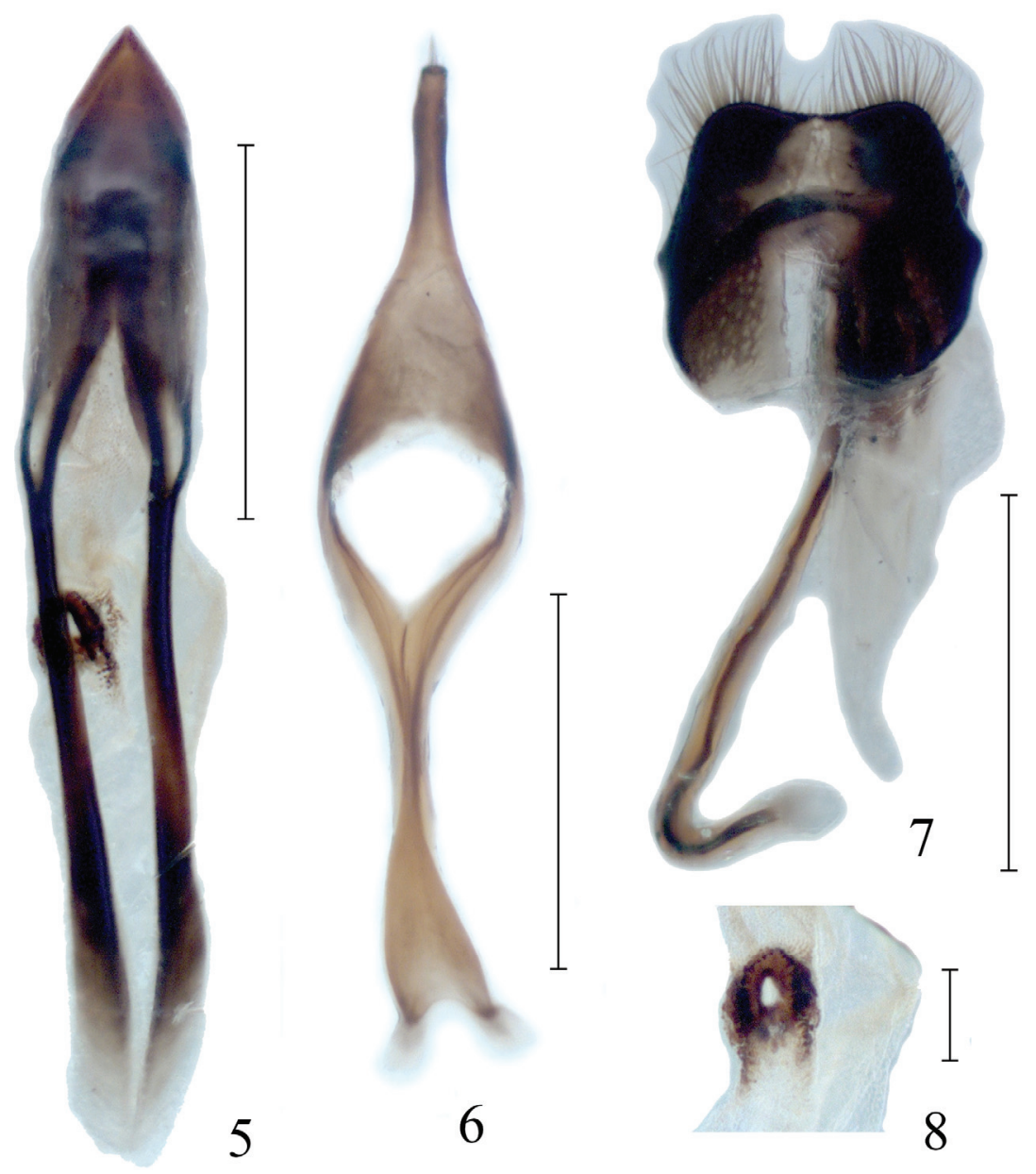

Figs 5-8. Exrhynchites storozhenkoi sp. n., holotype, genitalia, dorsal view: 5 - aedeagus; 6 - tegmen; 7 - tergite $8 ; 8$ - armament of endophallus. Scale bar $1.0 \mathrm{~mm}$ for figs $5-7$ and $0.2 \mathrm{~mm}$ for fig. 8 .

almost bell-shaped, 1.6 times as long as wide at apex, 1.1 times as long as wide in middle and at base. Disk weakly convex, densely punctate. Scutellum almost rhomboidal. Elytra 1.5 times as long as wide at base and at apical fourth, 1.3 times as long as wide in middle, 3.1 times as long as pronotum. Humeri weakly flattened. Elytral striae distinct. Striae 9 striae merge with striae 10 before metacoxa. Intervals flattened, punctate. Pre- and postcoxal portions of prosternum short. Procoxal cavities contiguous. Metanepisternum quite wide, punctuate, 1.7 times as long as wide in middle. Metaventrite weakly convex, punctate, 1.8 times as long as length of metacoxal cavity. Abdomen convex, densely punctate. Ventrites 1 and 2 fused. Ventrite 
10.7 times as long as length of metacoxa. Ventrite 21.1 times as long as ventrite 1 . Ventrite 30.6 times as long as ventrite 2. Ventrite 40.9 times as long as ventrite 3. Ventrite 50.8 times as long as ventrite 4 . Part of propygidium and pygidium exposed. Procoxae large, conical, with large pit and hair bunches. Metacoxae transverse. Trochanters small. Femora thickened, lacking teeth. Tibiae almost straight, with costate dorsal margin. Tarsi long. Tarsomere 1 conical. Tarsomere 2 wide-conical. Tarsomere 3 wide-bilobed. Tarsomere 5 elongate. Tarsal claws divergent, with long teeth. Armament of endophallus sclerotized (Fig. 8).

Female unknown.

COMPARISION. The new species differs from other species of the genus in the body without metallic blue luster, cowered with dense yellow-brown hairs, and sclerotized armament of the endophallus.

DISTRIBUTION. Vietnam: Lai Châu Prov.

ETYMOLOGY. The species is named in honor of Sergey Yu. Storozhenko (Vladivostok, Russia), who contributed to the study of East Asian insects.

\section{ACKNOWLEDGEMENTS}

I'm grateful to O. Jaeger (Germany: Dresden), K.- D. Klass (Germany: Dresden), M. Seidel (Germany: Hamburg), D. Kovac (Germany: Frankfurt-am-Main), B.A. Korotyaev (Russia: St. Petersburg) for the opportunity to study of types of the genus Exrhynchites.

\section{REFERENCES}

Lawrence, J.F., Beutel, R.G., Leschen, R.A.B. \& Ślipiński, S.A. 2010. Chapter 2. Glossary of Morphological Terms. P. 9-20. In: Handbook of Zoology. Arthropoda: Insecta. Tb. 40: Coleoptera (Beetles). Vol. 2: Morphology and Systematic (Elateroidea, Bostrichformia, Cucujiformia partim). Walter de Gruyter, Berlin, New York. 786 pp.

Legalov, A.A. 2004. A new classification of ecological groups of the leaf-rolling weevils (Coleoptera: Rhynchitidae, Attelabidae). Eurasian Entomological Journal, 3(1): 43-45. [In Russian]

Legalov, A.A. 2007. Leaf-rolling weevils (Coleoptera: Rhynchitidae, Attelabidae) of the world fauna. Agro-Siberia, Novosibirsk. 523 pp.

Sawada, Y. 1993. A systematic study of the family Rhynchitidae of Japan (Coleoptera, Curculionoidea). Humans and Nature, 2: 1-93. 